\title{
KINERJA KEUANGAN PERUSAHAAN DAN RISIKO SAHAM SERTA DAMPAKNYA TERHADAP RETURN SAHAM
}

\author{
Belinda Yuniandri Standyarto ${ }^{1}$ \\ Nicodemus Simu ${ }^{2}$ \\ Alumni FEB Perbanas Institute, Jakarta \\ Dosen FEB Perbanas Institute, Jakarta \\ nicosimu@yahoo.com
}

\begin{abstract}
Abstrak
Penelitian ini bertujuan untuk mengetahui dampak Current Ratio, Debt to Equity Ratio, Return on Asset dan beta terhadap return saham. Unit analisis adalah perusahaan subsektor property dan real estate pada Bursa Efek Indonesia. Variabel Prediktor yang digunakan dalam penelitian ini adalah current ratio, debt to equity ratio, return on assets, dan beta. Sementara variabel dependennya adalah return saham. Teknik pengambilan sampel yang digunakan adalah purposive sampling, dengan kriteria, yaitu (1) perusahaan Property dan Real Estate yang secara konsisten tercatat di Bursa Efek Indonesia periode 2011 - 2015 dan (2) mempublikasikan laporan keuangan tahunan yang telah diaudit dan tersedia di www.idx.co.id pada Juli 2016. Jumlah sampel yang digunakan dalam penelitian adalah 32 perusahaan dan dengan demikian diperoleh 160 data observasi. Metode analisis yang digunakan adalah analisis regresi berganda, serta uji hipotesis dilakukan melalui uji-t. Berdasarkan hasil analisis data yang telah dilakukan DER dan ROA memiliki pengaruh positif signifikan terhadap return saham. Sedangkan, variabel lainnya yaitu CR dan beta tidak memiliki pengaruh terhadap return saham.
\end{abstract}

Key words: Current Ratio, Debt to Equity Ratio, Return on Asset, Beta, Return saham

\section{Pendahuluan}

Salah satu tujuan investor dalam berinvestasi, baik investasi riil pada aktiva berujud maupun investasi keuangan adalah mendapatkan keuntungan di dalam bentuk peningkatan nilai asetnya. Sebagai manusia yang rasional, pilihan investasi yang dilakukan investor adalah investasi yang memberikan return yang tinggi, dengan tentu saja memperhatikan risiko yang menyertai investasi tersebut. Di dalam hal investasi pada surat berharga, misalnya saham, potensi keuntungan investor bersumber dari capital gain dan pembagian dividen. Total penjumlahan capital gain dengan dividen pada umumnya disebut dengan return saham. Besarnya return yang dijanjikan oleh masing-masing saham ini dapat dipengaruhi oleh berbagai macam faktor. Faktor-faktor tersebut antara lain adalah kinerja keuangan perusahaan--yang direpresentasikan melalui rasio keuangan--dan tingkat risiko yang dihadapi oleh perusahaan tersebut di dalam menjalankan bisnis.

Rasio keuangan adalah rasio yang digunakan sebagai alat ukur kondisi suatu perusahaan di dalam periode tertentu. Setiap rasio akan memberikan informasi yang berguna bagi investor baik untuk menilai kondisi keuangan suatu perusahaan maupun untuk mengambil keputusan investasi di dalam surat berharga. Keputusan untuk buy/sell/hold atas

\footnotetext{
${ }^{1}$ Alumni FEB Perbanas Institute, Jakarta

${ }^{2}$ Dosen FEB Perbanas Institute, Jakarta
} 
suatu saham dari sudut pandang investor umumnya bergantung pada hasil analisis rasio keuangan yang dilakukan oleh investor tersebut. Semakin baik informasi yang diberikan masing-masing rasio menjadi indikasi bahwa perusahaan dijalankan dengan baik dan akan berdampak pada keuntungan yang diperoleh perusahaan. Kondisi ini pada gilirannya juga berdampak pada harga saham dan dividen yang diterima investor.

Sejalan dengan adanya return yang dijanjikan, kepemilikan atas suatu saham atau surat berharga lainnya pada dasarnya juga mengandung risiko. Investasi yang menjanjikan return yang tinggi selalu disertai dengan risiko yang tinggi pula. Di dalam investasi surat berharga, investasi di dalam kepemilikan saham mengandung risiko yang lebih tinggi jika dibandingkan dengan tabungan, deposito atau pun investasi pada obligasi. Risiko yang terkandung di dalam investasi terdiri dari risiko sistematis dan risiko tidak sistematis. Risiko tidak sistematis dapat dihindari melalui diversifikasi. Risiko yang patut dipertimbangkan adalah risiko sistematis karena dengan kondisi pasar, bersifat umum dan berlaku bagi semua saham dalam bursa saham yang bersangkutan. Alat ukur risiko sistematis ini disebut dengan $\beta$ (beta). Husnan (2005:200) menyatakan bahwa return saham dengan risiko sistematis memiliki hubungan linier positif. Beta yang tinggi menunjukkan saham yang menjanjikan return tinggi sekaligus juga berarti saham yang disertai dengan risiko tinggi.

Penelitian mengenai kinerja keuangan terhadap return saham telah dilakukan oleh beberapa peneliti. Beberapa rasio keuangan yang dijadikan sebagai indikator ukuran kinerja keuangan tersebut antara lain current ratio (Ulupui, 2007; Malintan, 2011; Budialim, 2013; serta Nugroho dan Sukhemi, 2015), return on assets (Ulupui, 2007; Malintan, 2011; Susilowati dan Turyanto, 2011; dan Budialim, 2013), return on equity (Susilowati dan Turyanto, 2011; Budialim, 2013; Ismayanti dan Yusniar, 2014; dan Andansari, 2016), debt to equity ratio (Suharli, 2005; Ulupui, 2007; Malintan, 2011; Susilowati dan Turyanti, 2011; Hermawan, 2012, Budialim, 2013; dan Ismayanti dan Yusniar, 2014), earnings per share (Susilowati dan Turyanti, 2011; Hermawan, 2012; Nugroho dan Triyonowati, 2013; Budialim, 2013; Artaya, 2014; dan Ismayanti dan Yusniar, 2014), dan price earnings ratio (Malintan, 2011; Nugroho dan Triyonowati, 2013; Artaya, 2014; dan Ismayanti dan Yusniar, 2014; dan Andansari, 2016). Hasil penelitian seperti yang disebutkan di atas menunjukkan perbedaan pengaruh dari masing-masing variabel terhadap besaran return saham.

Di samping penelitian yang menggunakan rasio keuangan sebagai prediktor return saham, penelitian yang menguji dampak risiko saham terhadap return saham juga telah dilakukan beberapa peneliti. Secara umum, parameter pengukur risiko saham yang dijadikan sebagai variabel terdiri dari risiko sistematis dan risiko tidak sistematis. Namun demikian, sebagian besar penelitian tersebut menggunakan $\beta$ (beta) sebagai pengukur risiko investasi (Suharli, 2005; Budialim, 2013; Nugroho dan Triyonowati, 2013; Ismayanti dan Yusniar, 2014; Artaya, 2014; Paramitasari, 2014; Septiani dan Suparmi, 2014; serta Nugroho dan Sukhemi, 2015). Penelitian yang dilakukan dengan menggunakan variabel $\beta$ (beta) sebagai prediktor terhadap terjadinya return saham tersebut juga menunjukkan hasil temuan yang berbeda-beda, sebagian menunjukkan adanya pengaruh dan sebagian lagi menunjukkan tidak terjadinya pengaruh.

Penelitian ini mencoba untuk mengkaji kembali dampak dari beberapa kinerja keuangan perusahaan, seperti current ratio, debt to equity ratio, return on assets, dan juga risiko saham yang diwakili oleh $\beta$ terhadap pergerakan harga saham perusahaan, yang pada gilirannya akan juga berdampak terhadap return saham. Unit analisis di dalam penelitian ini adalah industri property dan real estate yang terdaftar di BEI. Menurut penelitian yang dilakukan oleh Cushman \& Wakefield Indonesia pada 2015, sampai dengan akhir 2016, perkiraan tingkat occupancy gedung perkantoran di Jakarta berada pada kisaran $90 \%$ dan demikian juga sampai dengan 2017, akan dibangun 20 gedung perkantoran dengan luas 1.000.000 meter persegi. Dengan demikian kiranya dapat dipahami bahwa industri ini 
merupakan industri yang sangat potensial dan masih berkembang pesat, dan patut untuk diteliti.

\section{Kajian Pustaka dan Pengembangan Hipotesis}

\section{Return Saham}

Menurut Gitman et. al. (2015:363) return is the total gain or loss experienced on an investment over a given period, calculated by dividing the asset's cash distributions during the period, plus change in value, by its beginning of period investment value. Menurut defenisi tersebut, return dinyatakan secara persentasi dan ditujukan untuk menyebutkan hasil investasi, baik investasi sektor riil maupun investasi pada produk keuangan. Sementra itu, Jogiyanto (2016:264) menyatakan bahwa return terdiri dari capital gain (loss) dan yield. Selanjutnya, yield merupakan presentase penerimaan yang dibayarkan setiap periodik kepada investor terhadap suatu investasi, capital gain (loss) merupakan selisih harga saham saat pembelian dengan harga saham saat penjualan.

Susilowati dan Turyanti (2011) mengemukakan bahwa keuntungan yang diperoleh perusahaan dapat berupa current income dan capital gain. Current income diperoleh investor melalui pembayaran yang bersifat periodik, misalnya bunga obligasi dan dividen, sementara dividen merupakan keuntungan yang dibagikan kepada para pemegang saham. Perolehan return saham yang tinggi merupakan suatu daya tarik dari saham tersebut. Mengacu pada teori pilihan rasional (rational choice theory), tidak dapat dipungkiri bahwa investor di dalam berinvestasi mengharapkan perolehan keuntungan, dan bukannya menderita kerugian.

\section{Likuiditas terhadap Return Saham}

Likuditas merupakan kemampuan suatu perusahaan untuk menyelesaikan kewajiban keuangan jangka pendeknya. Perusahaan yang mampu menyelesaikan kewajiban jangka pendeknya berarti cukup likuid. Keown dkk (2014: 133) menyatakan bahwa likuiditas perusahaan didefinisikan sebagai kemampuan untuk menyediakan kas pada saat dibutuhkan untuk memenuhi kewajiban keuangannya. Dengan kata lain, likuditas diartikan sebagai kemampuan perusahaan untuk membayar kewajiban secara tepat waktu. Secara spesifik, Subramanyam (2012) berpendapat bahwa likuiditas digunakan untuk mengevaluasi kemampuan perusahaan dalam memenuhi kewajiban jangka pendeknya. Melalui likuiditas, dapat diketahui kondisi dari arus kas perusahaan.

Pada umumnya, likuiditas dapat diukur dengan menggunakan rasio likuiditas. Terdapat beberapa rasio likuiditas, yaitu current ratio, quick ratio, dan cash ratio. Rasio yang paling umum digunakan current ratio. Rasio ini menunjukkan tingkat likuiditas perusahaan dengan membandingkan aset lancar perusahaan dengan kewajiban lancarnya. Rasio ini mengukur kemampuan perusahaan dalam membayar utang jangka pendek, menunjukkan jumlah ketersediaan aktiva lancar yang dimiliki suatu perusahaan untuk membayar semua kewajiban jangka pendek. Current ratio lebih mewakili keadaan arus kas suatu perusahaan karena merupakan salah satu ratio keuangan yang paling umum digunakan untuk menentukan kondisi perusahaan dalam melunasi kewajiban lancar. Selain itu, current ratio adalah parameter yang dapat digunakan untuk mengukur tingkat keamanaan (margin of safety) suatu perusahaan (Kasmir, 2014:111).

Semakin tinggi current ratio berarti modal kerja perusahaan semakin baik, aktiva lancar yang dimiliki perusahaan cukup likuid dan mampu digunakan untuk membayar kewajiban jangka pendek. Dengan begitu, minat investor untuk menginvestasikan saham pada perusahaan juga meningkat. Karena investor percaya bahwa perusahaan dapat 
memenuhi kewajiban saat ditagih. Apabila current ratio suatu perusahaan rendah, bisa saja diartikan bahwa aktiva lancar yang dimiliki perusahaan tidak cukup untuk membayar kewajiban jangka pendek, perusahaan perlu memperoleh dana dari tempat lain. Hal ini dapat membuat investor takut untuk berinvestasi pada perusahaan tersebut, karena dalam mencukupi kewajiban jangka pendeknya saja sudah sulit apalagi dalam memberikan performa yang baik dan memberikan keuntungan bagi investor. Peminat investor yang meningkat akan meningkatkan harga saham dan berpengaruh positif pada return yang akan diterima oleh perusahaan. Menurut Ulupui (2007) investor dapat memperoleh return lebih tinggi saat kemampuan perusahaan dalam memenuhi kewajiban jangka pendek semakin tinggi. Dengan demikian, hipotesis yang akan diuji adalah:

\section{$\mathrm{H}_{1}$ : Current ratio berpengaruh positif terhadap return saham}

\section{Debt to Equity Ratio terhadap Return Saham}

Solvabilitas digunakan sebagai pengukur kemampuan perusahaan dalam membayar kewajibannya apabila dilikuidasi. Di dalam implementasinya, solvabilitas diukur dengan rasio yang berkaitan dengan utang. Menurut Kasmir (2014:112), rasio solvabilitas mengukur proporsi aktiva yang dibiayai dengan utang. Rasio solvabilitas yang diwakili oleh Debt to Equity Ratio (DER) merupakan rasio yang digunakan untuk menilai utang dengan ekuitas (Kasmir, 2014:112) dan sekaligus untuk mengetahui setiap rupiah modal sendiri yang dijadikan sebagai agunan atas utang perusahaan.

DER mencerminkan struktur modal perusahaan yang akan menjadi sumber informasi penting bagi kreditur maupun investor. Jika modal sendiri lebih besar dari modal pinjaman, perusahaan dapat memenuhi seluruh kewajibannya. Gitman et. al. (2015:126) menyatakan bahwa a high debt to equity ratio is often viewed as an indication that a company may not be able to generate enough cash to satisty its debt obligations. Semakin tinggi DER, semakin berat bagi perusahaan untuk menyediakan alat likuid di dalam rangka memenuhi kewajibannya, dan ini berarti risiko perusahaan akan semakin meningkat sejalan karena meningkatnya utang perusahaan yang harus diselesaikan. Utang lebih tinggi juga mencerminkan meningkatnya potensi risiko yang akan ditanggung investor. Hal ini dapat membuat investor kurang percaya pada perusahaan tersebut. Kondisi ini akan membuat investor atau calon investor untuk menahan diri di dalam melakukan pembelian atas saham perusahaan. Dampak yang mungkin ditimbulkannya adalah menurunnya harga saham dan otomatis juga menurunkan return saham.

Hasil penelitian Malintan (2011) menunjukkan bahwa DER yang tinggi dapat memperbesar tanggung jawab perusahaan, beban bunga yang ditanggung semakin besar dan mengurangi keuntungan. Tingkat utang yang tinggi dan dibebankan kepada pemegang saham akan meningkatkan risiko investasi para investor. Hermawan (2012) dalam penelitiannya juga diperoleh hasil yang mengindikasikan bahwa DER yang tinggi mengakibatkan return saham menurun. Berdasarkan uraian di atas, hipotesis yang akan diuji adalah:

\section{$\mathrm{H}_{2}$ : Debt to Equity Ratio (DER) berpengaruh negatif terhadap return saham}

\section{Profitabilitas terhadap Return Saham}

Profitabilitas mencerminkan tingkat efektivitas manajemen suatu perusahaan yang dapat dilihat dari laba penjualan dan pendapatan investasi. Apabila manajemen menjalankan kegiatannya dengan efektif, laba dari penjualan dan pendapatan investasi akan meningkat. Semakin tinggi profitabilitasnya, suatu perusahaan memiliki tingkat efesiensi yang semakin 
tinggi. Profitabilitas yang tinggi dapat merupakan indikator kemampuan perusahaan dan secara tidak langsung dapat membangun prospek yang baik bagi perusahaan. Hal ini meningkatkan kepercayaan investor, meningkatkan harga saham di pasaran, return saham juga akan meningkat seiring dengan peningkatan harga saham. Profitabilitas diukur dengan rasio profitabilitas.

Rasio profitabilitas menurut Kasmir (2014:115) merupakan rasio untuk menilai kemampuan perusahaan dalam mencari keuntungan. Rasio profitabilitas diwakili oleh Return on Asset (ROA). ROA mengukur kemampuan perusahaan dalam menghasilkan laba melalui seluruh dana yang ditanamkan dalam aset perusahaan. ROA dapat mewakili jumlah laba atas investasi yang dimiliki perusahaan. ROA yang tinggi menggambarkan perusahaan tersebut cukup efisien, di dalam arti bahwa perusahaan dapat memanfaatkan seluruh aset yang dimilikinya untuk menghasilkan laba. Kemampuan perusahaan untuk mengelola asetnya secara efisien dapat meningkatkan kepercayaan investor, menarik minat investor terhadap saham akan meningkat, meningkatkan harga dan juga meningkatkan potensi return yang diperoleh

ROA memiliki hubungan positif terhadap return saham. Hasil penelitian Ulupui (2007) menunjukkan bahwa ROA memiliki pengaruh positif dan signifikan terhadap return saham. Temuan ini mengindikasikan bahwa semakin tinggi kemampuan perusahaan menghasilkan pendapatan, mengindikasikan bahwa semakin efisien perputaran aset perusahaan, yang berdampak secara langsung terhadap peningkatan nilai perusahaan. Hasil penelitian ini sejalan dengan penelitian yang dilakukan oleh Malintan (2011), yaitu semakin tinggi ROA maka kinerja perusahaan semakin baik. Mengacu kepada deskripsi di atas, maka hipotesis yang akan diuji adalah:

\section{$\mathrm{H}_{3}$ : Return on Assets (ROA) berpengaruh positif terhadap return saham}

\section{Risiko (Beta) terhadap Return Saham}

Risiko merupakan sesuatu yang tidak dapat dihindari di dalam investasi. Adanya risiko memberikan ruangan atas perbedaan return dari investasi tersebut. yang diharapkan oleh investor berbeda dari return yang sesungguhnya diperoleh setiap investor dari hasil investasi. Investor mengharapkan dapat memperoleh return atas setiap risiko investasi yang mungkin terjadi. Terjadinya risiko di dalam investasi merupakan suatu keniscayaan dan tidak dapat dihindari, setiap investasi yang dipilih memiliki risiko yang berbeda-beda. Risiko dalam investasi terdiri dari risiko sistematis dan risiko tidak sistematis. Risiko tidak sistematis merupakan risiko yang tidak dapat dieliminasi melalui diversifikasi mengingat risiko ini berkaitan dengan kondisi pasar secara umum dan akan tetap ditanggung oleh investor. Risiko tidak sistematis atau risiko pasar ini berkaitan dengan misalnya regulasi pemerintah dan kondisi makro ekonomi antara lain perubahan tingkat suku bunga, pergerakan nilai tukar, jumlah uang beredar, dan tingkat inflasi.

Parameter yang bisa digunakan untuk menghitung risiko sistematis adalah beta $(\beta)$. Menurut Gitman et. al. (2015:382) beta coefficient is a relative measure of nondiversifiable risk. An index of the degree of movement an asset's return in response to a change in the market return. Koefisien $\beta$ merupakan ukuran kepekaan risiko dengan memperhitungkan tingkat sensitivitas perubahan harga saham sebagai akibat perubahan kondisi pasar. $\beta$ dapat menjadi gambaran bagi investor, saham mana yang akan memberikan keuntungan tinggi dengan risiko tinggi, serta saham mana yang cenderung aman karena memiliki risiko yang rendah. Perubahan $\beta$ mengakibatkan perubahan return yang diharapkan oleh setiap investor. Apabila koefisien $\beta$ berubah semakin tinggi maka expected return akan semakin tinggi, demikian pula sebaliknya, jika koefisien $\beta$ semakin rendah maka expected return juga 
semakin rendah (Gitosudarmo dan Basri: 263 - 264). Gitman, et. al. (2015) menyatakan bahwa beta yang semakin tinggi akan menandakan semakin besar suatu sekuritas dihadapkan pada risiko sistematik dan semakin tinggi return yang harus ditawarkan bagi investor. Hal ini sejalan dengan hasil Penelitian Budialim (2013) yang menunjukkan bahwa beta berpengaruh positif signifikan terhadap return saham perusahaan, peningkatan beta akan meningkatkan return saham. Berdasarkan uraian di atas, hipotesis yang akan diuji adalah:

\section{$\mathrm{H}_{4}$ : Beta berpengaruh positif terhadap return saham}

\section{Metode Penelitian}

Penelitian ini tergolong jenis penelitian asosiatif kuantitatif. Variabel prediktor yang digunakan di dalam penelitian ini terdiri dari dua jenis, yaitu variabel yang bersumber dari kinerja keuangan, current ratio, debt to equity ratio, return on asset. Sementara variabel prediktor sebagai proksi dari risiko saham adalah beta $(\beta)$. Di sisi lain, variabel dependennya adalah return saham. Populasi pada penelitian ini adalah seluruh perusahaan Real Estate dan Property yang terdaftar di Bursa Efek Indonesia. Pemilihan sampel dalam penelitian ini menggunakan metode purposive sampling, dengan menggunakan dua kriteria, yaitu: (1) Perusahaan_Property dan Real Estate yang secara konsisten tercatat di Bursa Efek Indonesia periode 2011 - 2015 dan (2) mempublikasikan laporan keuangan tahunan yang telah diaudit dan tersedia di www.idx.co.id pada Juli 2016. Berdasarkan kriteria tersebut, maka jumlah perusahaan yang dijadikan sampel adalah sebanyak 32 perusahaan dan menghasilkan 160 data observasi. Pengumpulan data dilakukan dari berbagai sumber. Data variabel CR, DER, dan ROA diperoleh dari Company Report dan Laporan Keuangan Tahunan perusahaan yang telah diaudit serta diperoleh melalui www.idx.co.id. Sedangkan untuk data beta dan return menggunakan data IHSG dan data harga saham individual melalui close price adjusted for dividends and splits di www.yahoofinance.com, melalui angka tersebut dihitung menggunakan rumus sehingga diperoleh beta dan return untuk setiap perusahaan.

Tabel di bawah ini menunjukkan definisi operasional masing-masing variabel yang digunakan di dalam penelitian ini, baik sebagai variabel dependen maupun sebagai variabel prediktor.

Tabel 1: Operasionalisasi Variabel

\begin{tabular}{|l|l|c|l|}
\hline \multicolumn{1}{|c|}{ Variabel } & \multicolumn{1}{|c|}{ Konsep Variabel } & Ukuran & Skala \\
\hline $\begin{array}{l}\text { Return Saham } \\
\text { (R) }\end{array}$ & Capital gain (loss) + yield & $\frac{P_{t}-P_{t-1}+D_{t}}{P_{t-1}}$ & Rasio \\
\hline $\begin{array}{l}\text { Current Ratio } \\
\text { (CR) }\end{array}$ & $\begin{array}{l}\text { Tingkat likuiditas perusahaan } \\
\text { dengan membandingkan aset } \\
\text { lancar perusahaan dengan } \\
\text { kewajiban lancar }\end{array}$ & $\frac{\text { Current Asset }}{\text { Current Liabilities }}$ & Rasio \\
$\begin{array}{l}\text { Debt to Equity } \\
\text { Ratio } \\
\text { (DER) }\end{array}$ & $\begin{array}{l}\text { Perbandingan utang dengan } \\
\text { ekuitas }\end{array}$ & $\frac{\text { Total Lialibilities }}{\text { Total Equity }}$ & Rasio \\
\hline $\begin{array}{l}\text { Return on Asset } \\
\text { (ROA) }\end{array}$ & $\begin{array}{l}\text { Mengukur kemampuan } \\
\text { perusahaan dalam menghasilkan } \\
\text { laba melalui seluruh dana yang } \\
\text { ditanamkan dalam aset } \\
\text { perusahaan }\end{array}$ & $\frac{\text { Net Income }}{\text { Total Asset }}$ & Rasio \\
\hline
\end{tabular}




\begin{tabular}{|l|l|c|c|}
\hline \multicolumn{1}{|c|}{ Variabel } & \multicolumn{1}{|c|}{ Konsep Variabel } & Ukuran & Skala \\
\hline $\begin{array}{l}\text { Beta } \\
(\beta)\end{array}$ & $\begin{array}{l}\text { A relative measure of } \\
\text { nondiversifiable risk. An index } \\
\text { of the degree of movement an } \\
\text { asset's return in response to a } \\
\text { change in the market return. }\end{array}$ & $\beta_{i}=\frac{\operatorname{Cov}\left(R_{i,} R_{M}\right)}{\sigma^{2}\left(R_{M}\right)}$ & Rasio \\
\end{tabular}

Sumber: Peneliti (2016), diolah

Analisis data di dalam penelitian ini menggunakan analisis regresi linier berganda (multiple regression model) sebagai alat analisis utama. Uji signifikansi pengaruh masingmasing variabel prediktor terhadap variabel dependen menggunakan uji-t ( $t$-test), sementara pengujian goodness of fit akan menggunakan uji-F (F-test). Pengujian untuk mengukur besarnya kontribusi variabel prediktor terhadap variasi variabel dependen menggunakan koefisien determinasi, yaitu koefisien determinasi yang disesuaikan atau Adjusted $R$ Square.

Secara umum, model regresi linier berganda yang diajukan adalah sebagai berikut.

$$
\begin{aligned}
& \mathrm{R}=\alpha+\mathrm{b}_{1} \mathrm{CR}+\mathrm{b}_{2} \mathrm{DER}+\mathrm{b}_{3} \mathrm{ROA}+\mathrm{b}_{4} \beta+\mathrm{e} \\
& \text { Dimana: } \\
& \mathrm{R}=\text { Return saham } \\
& \mathrm{CR} \quad=\text { Current ratio } \\
& \text { DER = Debt to Equity Ratio } \\
& \text { ROA }=\text { Return on Asset } \\
& \beta=\text { Risiko (beta) } \\
& \alpha \quad=\text { Konstanta } \\
& \mathrm{b}_{1}, \mathrm{~b}_{2}, \mathrm{~b}_{3}, \mathrm{~b}_{4}=\text { Koefisien regresi masing-masing CR, DE, ROA, dan } \beta \\
& \text { e }=\text { standar error }
\end{aligned}
$$

\section{Hasil dan Pembahasan}

Analisis data terhadap ke-32 perusahaan sampel penelitian dan menggunakan 5 (lima) tahun periode data, menghasilkan 160 data untuk masing-masing variabel. Statistik deskriptif dari data yang dianalisis ditunjukkan pada tabel berikut.

Tabel 2: Statistik Deskriptif

\begin{tabular}{|l|r|r|r|r|r|}
\hline & RETURN & CR & DER & \multicolumn{1}{c|}{ ROA } & \multicolumn{1}{c|}{ BETA } \\
\hline Mean & 2.798868 & 1.948568 & 0.825483 & 5.939330 & 1.200725 \\
\hline Median & 1.816060 & 1.494795 & 0.725611 & 5.595000 & 1.154972 \\
\hline Maximum & 58.52177 & 7.827660 & 2.850000 & 31.61000 & 4.808478 \\
\hline Minimum & -5.695565 & 0.195135 & 0.077094 & -10.27000 & -2.439141 \\
\hline Std. Dev. & 6.246103 & 1.376070 & 0.501002 & 6.051509 & 1.268164 \\
\hline Observations & 160 & 160 & 160 & 160 & 160 \\
\hline
\end{tabular}

Sumber: Peneliti (2016). Diolah

Berdasarkan tabel di atas terlihat bahwa besaran return terendah adalah $-5,70 \%$ dan tertinggi 58,52\%, dengan rata-rata sebesar 2,7989\% dan standar deviasinya sebesar 6,24610. Sementara itu, pada variabel current ratio, rasio terendah sebesar $19,51 \%$ dan tertinggi $783 \%$. Nilai rata-rata current ratio adalah $194,86 \%$ dan standar deviasinya 1,376 . Selanjutnya untuk 
variabel DER, nilai terendah sebesar $7,71 \%$, rata-rata $82,55 \%$, dan nilai tertinggi $285 \%$. Standar deviasi DER adalah 0,501. Variabel ROA memiliki nilai terendah $-10,27 \%$, nilai tertinggi 31,61\%, dengan rata-rata sebesar 5,939\% dan standar deviasinya adalah 6,05151. Variabel terakhir, yaitu beta memiliki nilai terendah sebesar $-2,44$, sementara nilai tertingginya adalah 4,81, rata-rata koefisien beta adalah sebesar 1,2007 dan standar deviasi 1,268 .

\section{Uji Asumsi Klasik}

Uji asumsi klasik dilakukan agar data-data yang digunakan di dalam penelitian ini memenuhi asumsi best linear unbiased estimation (BLUE). Untuk itu, pengujian asumsi klasik akan meliputi uji normalitas, uji autokorelasi, uji heteroskedastisitas, dan uji multikolinearitas.

\section{Uji Normalitas}

Uji normalitas digunakan untuk memastikan data residual yang terbentuk dari model regresi memiliki distribusi normal. Gambar berikut menunjukkan hasil uji normalitas.

Gambar 1: Uji Normalitas

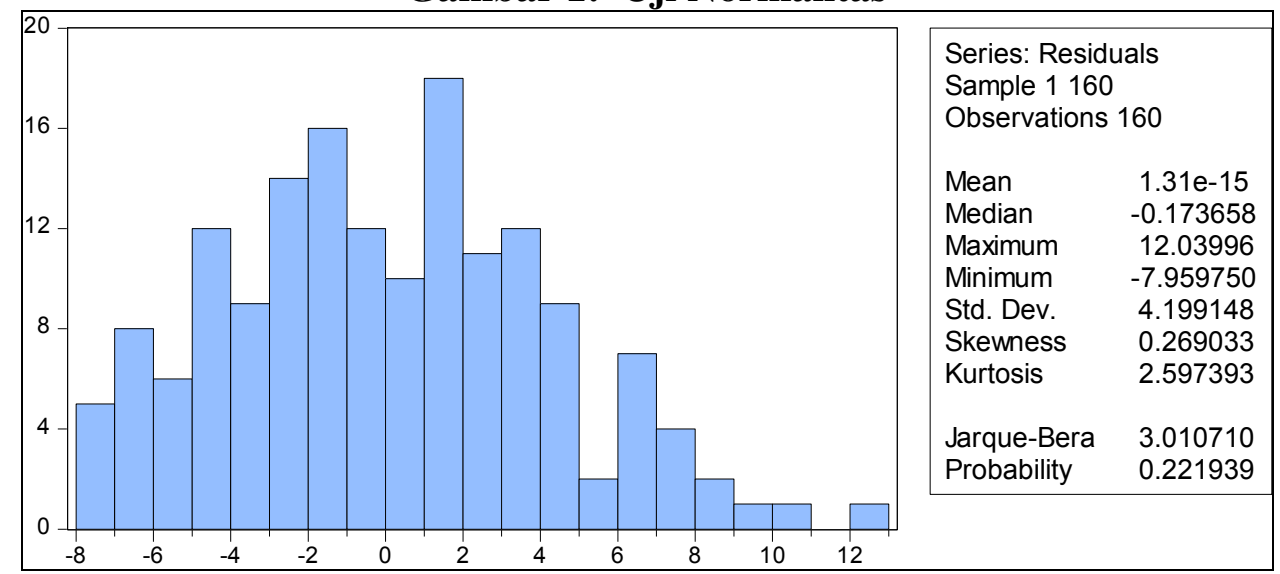

Sumber: Peneliti (2016), diolah

Pada data di atas dapat dilihat bahwa nilai Jarque-Bera sebesar 3,01 yang artinya lebih besar dari 0,05 (5\%). Oleh karena itu, dapat disimpulkan bahwa data terdistribusi secara normal.

\section{Uji Autokolerasi}

Uji autokolerasi digunakan untuk mengetahui ada tidaknya korelasi antara faktor pengganggu satu dengan lainnya. Pengujian autokolerasi dilakukan melalui koefisien DurbinWatson. 
Tabel 3: Uji Autokorelasi

\begin{tabular}{|ll|}
\hline \hline Mean dependent vax & 2.798871 \\
S.D. dependent var & 6.246105 \\
Akaike info criterion & 6.452647 \\
Schwarz criterion & 6.548746 \\
Hannan-Quinn criter. & 6.491670 \\
Durbin-Watson stat & 2.206015 \\
\hline
\end{tabular}

Sumber: Peneliti (2016), diolah

Data yang diuji tidak mengalami autokorelasi apabila dU $<$ DW $<4$-dU. Berdasarkan jumlah sampel $(\mathrm{n})=160$, variabel bebas $(\mathrm{k})=4$, maka dapat diketahui bahwa 1,7930<2,206 $<$ 2,207, sehingga dapat disimpulkan bahwa data yang diuji terbebas dari adanya autokorelasi.

\section{Uji Heteroskedastisitas}

Uji heteroskdeastisitas digunakan untuk menguji perbedaan varians residual suatu periode pengamatan ke periode pengamatan lain. Prediksi tersebut dapat dilihat melalui pola gambar residual, yang dapat dilihat hasilnya pada tabel berikut ini.

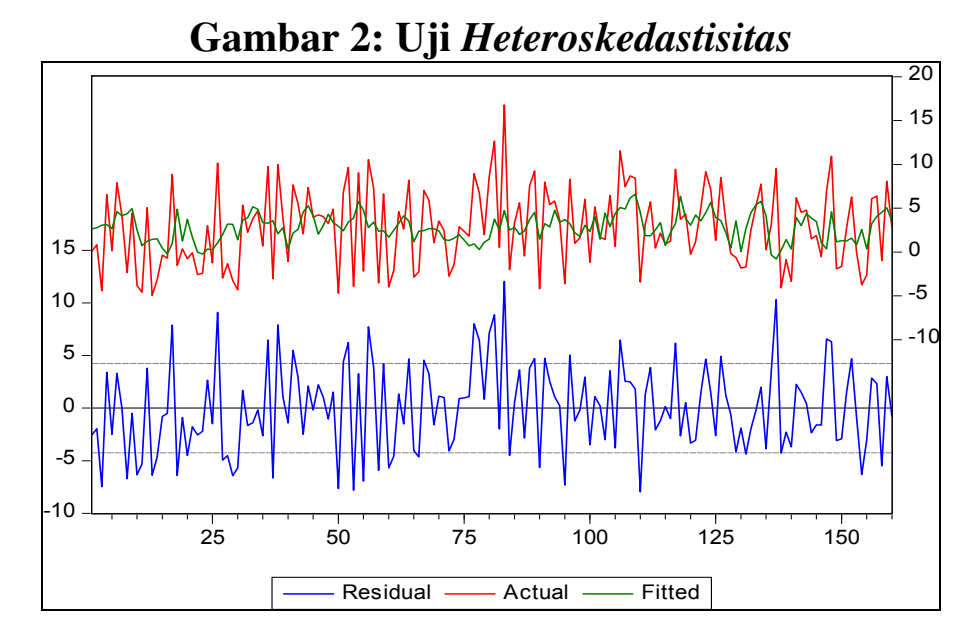

Sumber: Peneliti (2016), diolah

Melalui pola di atas, dapat dilihat bahwa residualnya tidak membentuk pola tertentu yang teratur dan data tersebar secara acak di sekitar garis angka 0, sehingga dapat disimpulkan bahwa pada model regresi tidak terjadi heteroskedastisitas.

\section{Uji Multikolinearitas}

Uji multikolinearitas dilakukan untuk mengetahui terdapat atau tidaknya hubungan atau korelasi yang signifikan antar variabel independen. Berikut adalah tabel hasil uji multikolinearitas. 
Tabel 4: Uji Multikolinearitas

\begin{tabular}{|l|c|c|c|c|r|}
\hline & DER & BETA & ROA & RETURN & \multicolumn{1}{c|}{ CR } \\
\hline DER & 1.000000 & 0.286892 & 0.069438 & 0.229826 & -0.244405 \\
\hline BETA & 0.286892 & 1.000000 & 0.052639 & 0.183773 & 0.002676 \\
\hline ROA & 0.069438 & 0.052639 & 1.000000 & 0.198449 & -0.106990 \\
\hline RETURN & 0.229826 & 0.183773 & 0.198449 & 1.000000 & -0.072291 \\
\hline CR & -0.244405 & 0.002676 & -0.106990 & -0.072291 & 1.000000 \\
\hline
\end{tabular}

Sumber: peneliti (2016), diolah

Pada tabel di atas terlihat bahwa besaran koefisien korelasi antar variabel bebas semuanya menunjukan angka sebesar kurang dari 0,8. Dengan demikian dapat disimpulkan tidak terjadi multikolinearitas.

\section{Analisis Regresi Linier Berganda} berikut.

Pengolahan data dengan menggunakan software statistik menunjukkan hasil sebagai

Tabel 5: Hasil Estimasi Model Regreasi

\begin{tabular}{|crrrr|}
\hline \hline Variable & Coefficient & Std. Error & t-Statistic & Prob. \\
\hline \hline CR & -0.043416 & 0.359457 & -0.120783 & 0.9040 \\
DER & 2.242408 & 1.026329 & 2.184882 & 0.0304 \\
ROA & 0.184211 & 0.079253 & 2.324337 & 0.0214 \\
BETA & 0.604843 & 0.393329 & 1.537753 & 0.1261 \\
C & -0.787942 & 1.380960 & -0.570576 & 0.5691 \\
\hline \hline
\end{tabular}

Sumber: Peneliti (2016), diolah

Berdasarkan hasil analisis pada tabel tersebut, diperoleh persamaan sebagai berikut:

$$
\text { Return Saham }=-0,788-0,043 \mathrm{CR}+2,242 \mathrm{DER}+0,184 \mathrm{ROA}+0,605 \beta
$$

Interpretasi dari persamaan di atas adalah bahwa apabila tidak terdapat variabel $\mathrm{CR}$, DER, ROA dan beta, maka besarnya return saham adalah -0,788. Selanjutnya--dengan asumsi variabel lain tidak berubah--perubahan sebesar satu persen pada CR akan menyebabkan penurunan return saham sebesar 4,3\%. Sebaliknya, asumsi variabel lain tidak berubah, perubahan sebesar satu persen pada masing-masing nilai DER, ROA, dan Beta akan menyebabkan peningkatan return saham secara berurutan adalah sebesar 224,2\%, 18,4\%, dan $60,5 \%$. 
Tabel 6: Tabel Uji F

\begin{tabular}{|lr|}
\hline \hline R-squared & 0.100014 \\
Adjusted R-squared & 0.076789 \\
S.E. of regression & 6.001500 \\
Sum squared resid & 5582.790 \\
Log likelihood & -511.2118 \\
F-statistic & 4.306235 \\
Prob(F-statistic) & 0.002485 \\
\hline \hline
\end{tabular}

Sumber: Peneliti (2016), diolah

Berdasarkan tabel 6 di atas terlihat bahwa besarnya nilai Prob (F-statistic) adalah sebesar 0,002, dan nilai lebih rendah daripada 5\%. Dengan demikian model persamaan regresi regresi yang diperoleh layak digunakan untuk menjelaskan perubahan return saham sebagai akibat dari perubahan-perubahan pada Current Ratio, Debt to Equity Ratio, Return on Asset, dan risiko (beta). Meskipun demikian besarnya pengaruh seluruh variabel terhadap return saham--yang ditunjukkan dengan koefisien Adjusted $R$-Square--relatif rendah, yaitu sebesarnya $7,7 \%$.

Mengacu pada hasil analisis pada tabel 5, pengujian hipotesis penelitian dengan menggunakan uji-t menunjukkan bahwa besaran nilai prob untuk variabel DER dan ROA lebih rendah dari pada 5\%, yaitu sebesar 0,0304 dan 0,0214. Dengan demikian dapat disimpulkan bahwa DER dan ROA memiliki pengaruh signifikan terhadap return saham. Hasil yang berbeda terlihat pada variabel $\mathrm{CR}$ dan $\beta$ yang menunjukkan nilai prob kedua masing-masing sebesar 0,9040 dan 0,1261 . Nilai prob kedua variabel ini berada di atas 0,05 dan berarti bahwa kedua variabel ini tidak berpengaruh signifikan terhadap return saham.

Penelitian ini mengajukan hipotesis kedua bahwa DER berpengaruh negatif signifikan terhadap harga saham. Hasil penelitian ini menemukan fakta yang berbeda, yaitu DER berpengaruh positif signifikan terhadap return saham. Pada umumnya, utang merupakan indikator yang terlihat secara nyata oleh investor. Sebagian investor berasumsi bahwa penggunaan utang yang tinggi selalu disertai dengan risiko yang meningkat, terutama yang berkaitan dengan kemampuan perusahaan untuk memenuhi semua kewajiban keuangannya. Perusahaan yang bernilai tinggi akan cenderung memiliki lebih banyak utang dibandingkan perusahaan yang bernilai lebih rendah. Cost of debt yang tinggi merupakan penghambat perusahaan dengan nilai rendah untuk berutang lebih banyak. Bagi perusahaan properti dengan aset besar, utang tersebut dimanfaatkan di dalam pembiayaan properti, dan sepanjang dapat secara rutin memberikan cash inflow bagi perusahaan, hal itu tidak dipandang buruk bagi investor. Kepemilikan aset likuid yang tinggi menjamin kelancaran untuk membayar biaya utang yang timbul. Selain itu, penggunaan utang yang banyak juga menandakan bahwa perusahaan memiliki kemampuan membayar kembali bunga utang beserta prinsipalnya.

Data supply dan demand properti (mall) Jakarta, Depok, Bogor, Tangerang, dan Bekasi secara konstan menunjukkan peningkatan selama kurun waktu 2011-2015. Statistik ini sekaligus menjadi indkator bahwa meskipun besaran DER mengalami peningkatan, tetapi peningkatan tersebut digunakan diinvestasikan kembali menjadi properti. Sepanjang jumlah permintaan (yang dibuktikan dengan peningkatan tingkat okupansi mall) dapat mengimbangi supply properti yang tersedia, investor atau calon investor saham perusahaan mengasumsikan tetap terjadi net cash inflow bagi perusahaan. Dengan demikian, perusahaan memiliki kinerja yang baik dalam menghasilkan keuntungan dan return saham, serta menambah menambah kepercayaan investor. Hasil penelitian ini didukung oleh penelitian Susilowati (2011) dan Ismyanti dan Yusniar (2014) yang menunjukkan bahwa DER memiliki pengaruh positif dan signifikan terhadap return saham, namun berbanding terbalik dengan penelitian Hermawan 
(2012) yang menyatakan sebaliknya. Hasil penelitian ini juga berbeda dengan penelitian Suharli (2005), Ulupui (2007), Melintan (2011), Budialim (2013) yang menyatakan DER tidak berpengaruh signifikan terhadap return saham.

Hasil penelitian ini mendukung hipotesis ketiga bahwa ROA berpengaruh positif dan signifikan terhadap return saham diterima. ROA merupakan rasio yang mengukur kemampuan perusahaan dalam menghasilkan laba melalui seluruh dana yang ditanamkan dalam aset perusahaan. Semakin tinggi ROA menandakan perusahan cukup baik dalam mengelola asetnya untuk memperoleh keuntungan. Selanjutnya, semakin tinggi ROA, kepercayaan investor untuk menanamkan modal pada perusahaan akan meningkat. Hal ini terjadi karena investor percaya perusahaan dapat memanfaatkan aset dengan baik agar dapat menghasilkan keuntungan bagi perusahaan. Keuntungan yang semakin tinggi akan berdampak pada meningkatnya harga saham yang selanjutnya meningkatkan return. Hasil ini juga didukung oleh hasil penelitian Ulupui (2007) dan Malintan (2011), semakin tinggi ROA maka kinerja perusahaan dipandang semakin baik oleh investor, perusahaan dapat memanfaatkan aset yang dimiliki dengan baik sehingga dapat menghasilkan pendapatan. Sebaliknya, penelitian ini menemukan hasil yang berbeda dibandingkan dengan penelitian Susilowati dan Turyanto (2011) dan Budialim (2013), yaitu ROA tidak berpengaruh signifikan terhadap return saham.

Penelitian ini menemukan bahwa current ratio tidak berpengaruh signifikan terhadap return saham dan hasil ini tidak sesuai dengan hipotesis pertama. Menurut Ross et. al. (2010 : 104), current ratio yang tinggi secara langsung menunjukkan alat likuid perusahaan terlalu banyak dan sekaligus mengindikasikan bahwa perusahaan tidak efisien dalam menggunakan uang kas serta aset jangka pendek yang dimiliki. Dengan bahasa yang berbeda, current ratio yang tinggi adalah indikator adanya idle money. Umumnya, idle money tersebut tidak menghasilkan uang, yang bisa diartikan managemen perusahaan tidak memanfaatkan aset yang dimiliki dengan baik.

Gitman et. al. (2015) menyatakan bahwa current ratio yang tinggi memang menandakan likuiditas yang semakin baik. Namun demikian, patut dipahami bahwa kebutuhan likuiditas pada setiap industri dan perusahaan berbeda-beda, nilainya sangat tergantung pada beberapa hal, termasuk antara lain ukuran perusahaan atau pun tingkat volatilitas bisnis yang dihadapi. Aset likuid yang tinggi tersebut akan lebih baik didistribusikan kembali ke dalam investasi yang menguntungkan, sehingga dapat memberikan tingkat pengembalian yang lebih tingi pula. Pada saat memutuskan untuk investasi, tujuan investor adalah mempertahankan dan meningkatan kesejahteraannya dan ini hanya dapat diperoleh apabila perusahaan mendapatkan keuntungan. Apabila perusahaan tidak menunjukkan kinerja yang baik, termasuk tidak bijaksana di dalam memanfaatkan aset lancar yang dimiliki, kepercayaan investor terhadap perusahaan akan menurun. Dikaitkan dengan industri yang dijadikan dasar penelitian ini, dapat disebutkan bahwa perusahaan di sub sektor property dan real estate tidak membutuhkan aset lancar yang besar, oleh karena itu, aset lancar tersebut seharusnya digunakan untuk diinvestasikan kembali agar lebih maksimal lagi dalam menghasilkan keuntungan. Hasil penelitian ini didukung oleh Malintan (2011) dan Budialim (2013), namun tidak sejalan dengan temuan Ulupui (2007) yang menyatakan bahwa current ratio berpengaruh positif signifikan terhadap return saham.

Hipotesis ke-4 menyatakan bahwa beta berpengaruh positif terhadap return saham. Gitman, et. al. (2015) menyatakan bahwa beta yang semakin tinggi akan menandakan semakin besar suatu sekuritas dihadapkan pada risiko sistematik. Semakin tinggi risiko sistematik yang membayangi suatu sekuritas, maka semakin tinggi pula return yang harus ditawarkan bagi investor. Penelitian ini menemukan bahwa $\beta$ tidak memiliki pengaruh terhadap return saham. Hasil serupa sejalan dengan penelitian Suharli (2005), Nugroho dan Triyonowati (2013), Artaya (2014), serta Septiani dan Suparmi (2014). Di sisi lain, Budialim 
(2013), Ismayanti dan Yusniar (2014), dan Paramitasari (2014) menemukan bahwa $\beta$ berpengaruh positif dan signifikan terhadap return saham atau penelitian Nugroho dan Sukhemi (2015) yang menemukan bahwa $\beta$ berpengaruh negatif dan signifikan terhadap return saham dan hasil-hasil penelitian ini berbeda dengan temuan di dalam penelitian ini.

Beta adalah menunjukkan risiko. Risiko yang dimaksudkan di sini merupakan risiko yang tidak dapat dihindarkan, termasuk dengan melalui serangkaian upaya diversifikasi portofolio karena berkaitan dengan kondisi pasar secara umum. Di dalam penelitian ini, disinyalir bahwa beta bukan merupakan suatu faktor yang diperhatikan oleh investor dalam memutuskan untuk berinvestasi. Hal ini disebabkan karena pada dasarnya semua industri pasti dihadapkan pada risiko. Oleh karena itu, dianggap bahwa risiko merupakan suatu kenicayaan. Selain itu, para investor kiranya memandang prospek industri sebagai suatu faktor yang cukup dominan untuk menentukan pertimbangan investasi. Sepanjang industri Real Estate dan Property memiliki prospek pertumbuhan yang baik, baik pada sisi supply maupun dari aspek permintaan, investor akan tetap tertarik untuk menanamkan dana pada industri ini. Berdasarkan data sales rate dan supply, dalam hal ini diwakili oleh condominium (apartemen dengan hak milik), sejak 2009 sampai dengan prediksi 2016, diperoleh fakta bahwa tingkat penjualan (sales rate) apartemen dengan hak milik di Jabodetabek tahun 20112015 cenderung stabil dan mendekati tingkat 100\%. Demikian pula data tingkat pra penjualan (pre-sales rate) yang menunjukkan kondisi yang stabil. Supply condominium cendung meningkat dari tahun ke tahun, bahkan di tahun 2016 ini diprediksikan meningkat dengan peningkatan yang cukup tinggi. Selain itu, sepanjang 2011-2015, jumlah proposed supply terus mengalami peningkatan, dan terakhir, seperti disebutkan pada bagian sebelumnya, tingkat occupancy mall juga mengalami peningkatan yang tinggi dan konstan. Berbekal gambaran kondisi yang cukup optimis ini kiranya cukup wajar apabila investor memiliki image positif terhadap kinerja perusahaan tersebut di dalam mempertahankan tingkat keuntungan dan membuat investor yakin bahwa menginvestasikan dana mereka pada industri properti memiliki prospek yang baik, tanpa harus memperhatikan besaran beta perusahaan.

\section{Kesimpulan}

Berdasarkan pembahasan pada bagian sebelumnya, berikut adalah kesimpulan yang dapat diambil, yaitu (1) debt to equity ratio (DER) berpengaruh positif dan signifikan terhadap return saham; (2) Return on asset (ROA) berpengaruh positif dan signifikan terhadap return saham; dan (3) Current ratio (CR) serta beta ( $\beta$ ) tidak berpengaruh terhadap return saham perusahaan subsektor property dan real estate pada Bursa Efek Indonesia.

\section{Daftar Pustaka}

Ross, Stephen, Westerfield W., Randolph, dan Jaffe, Jeffrey. (2010). “Coorporate Finance $9^{\text {th }}$ Edition". New York: The McGraw - Hill.

Andansari, Neni Awika. (2016). "Pengaruh Return on Equity (ROE), Price Earning Ratio (PER), Total Asset Turn Over (TATO) dan Price to Book Value (PBV) terhadap Return Saham (Studi Kasus pada Perusahaan Manufaktur Sektor Makanan dan Minuman yang terdaftar di BEI Periode 2008 - 2014)". Journal of Accounting: Vol. 2, No. 2

Artaya, Made, Ida Bagus Anom Purbawangsa, dan Luh Gede Sri Artini. (2014). "Pengaruh Faktor Ekonomi Makro, Risiko Investasi, dan Kinerja Keuangan Terhadap Return Saham Perusahaan di Bursa Efek Indonesia (BEI)". E-Jurnal Ekonomi dan Bisnis: Universitas Udayana, 3.12. 
Budialim, Giovanni. (2013). "Pengaruh Kinerja Keuangan dan Risiko terhadap Return Saham Perusahaan Sektor Consumer Goods di Bursa Efek Indonesia Periode 2007 - 2011". Jurmal Ilmiah Mahasiswa: Universitas Surabaya, Vol. 2 No.1.

Cushman \& Wakefield Indonesia Research. (2016)."Jakarta Property Market Overview Q2 2016".

--------. (2015)."Property Market Outlook 2016".

Gitman, J. Lawrence dan Zutter, Chad J. (2015). "Principles of Managerial Finance, $14^{\text {th }}$ Edition”. England: Pearson Education Limited.

Gitosudarmo, Indriyo dan Basri. (2013). "Manajemen Keuangan Edisi Keempat". Yogyakarta: BPFE Yogyakarta.

Hartono, Jogiyanto. (2016). “Teori Portfolio dan Analisis Investasi Edisi 10”. Yogyakarta: BPFE Yogyakarta.

Hermawan, Dedi Aji. (2012). "Pengaruh Debt to Equity Ratio, Earning Per Share dan Net Profit Margin terhadap Return Saham”. Management Analysis Journal: 1 (5).

Ismayanti, Diah dan Meina Wulansari Yusniar. (2014). "Pengaruh Faktor Fundamental dan Risiko (Beta) Terhdap Return Saham pada Perusahaan Yang Termasuk Dalam Indeks LQ-45”. Jurnal Wawasan Manajemen: Vol. 2, No. 1.

Kamaludin dan Indriani, Rini. (2012). Manajemen Keuangan "Konsep Dasar dan Penerapannya Edisi Revisi”. Bandung: CV. Mandar Maju.

Kasmir. (2010). "Pengantar Manajemen Keuangan Edisi Kedua”. Jakarta: Prenadamedia Group.

Keown, Arthur J., John D. Martin, dan J. William Petty. (2014). "Foundation of Finance: The Logic and Practice of Financial Management", 8th edition. Edinburg Gate, Harlow, Essex, England, Pearson Education Limited.

Malintan, Rio. (2011). "Pengaruh Current Ratio (CR), Debt to Equity Ratio (DER), Price Earning Ratio (DER) dan Return on Asset (ROA) terhadap Return Saham Perusahaan Pertambangan yang Terdaftar di Bursa Efek Indonesia tahun 2005 - 2010”. Jurnal Ilmiah Mahasiswa Fakultas Ekonomi dan Bisnis: Vol. 1 No. 1.

Nugroho, Imron Joko dan Triyonowati. (2013). "Pengaruh Risiko Sistematis dan Faktor Fundamental Terhadap Return Saham Perusahaan Otomotif”. Jurnal Ilmu \& Riset Manajemen: Vol. 2, No. 12.

Nugroho, Inggit dan Sukhemi. (2015). "Pengaruh Risiko Sistematis dan Likuiditas Terhadap Return Saham pada Perusahaan manufaktur Yang Terdaftar di BEI". Jurnal Akuntansi: Vol. 3, No. 2

Paramitasari, Ratih. (2014). "Pengaruh Risiko Sistematis dan Risiko Tidak Sistematis Terhadap Expected Return Saham Dalam Rangka Pembentukan Portofolio Saham LQ-45 Yang Terdaftar di Bursa Efek Indonesia Dengan Single Index Model Periode Tahun 200”. Jurnal Organisasi dan Manajemen: Vol. 10, No. 1.

Septiani, Ni Nyoman Devi dan Ni Luh Supadmi. (2014). “Analisis Pengaruh Beta Terhadap return Saham Periode Sebelum dan Saat Krisis Global (Studi pada Perusahaan Perbankan di BEI)". E-Jurnal Akuntansi: Universitas Udayana, 7.1 
Subramanyam. K. R. dan Wild, John J. (2012). "Financial Statement Analysis $10^{\text {th }}$ Edition". New York: The McGraw - Hill.

Suharli, Michell. (2005). "Studi Empiris terhadap Dua Faktor yang Mempengaruhi Return Saham pada Industri Food \& Beverages di Bursa Efek Jakarta”. Jurnal Akuntansi \& Keuangan: Vol. 7, No. 2.

Susilowati, Yeye dan Tri Turyanto. (2011). "Reaksi Signal Rasio Profitabilitas dan Rasio Solvabilitas terhadap Return Saham Perusahaan". Dinamika Keuangan dan Perbankan, Vol. 3, No. 1.

Ulupui, I G. K. A. (2007). “Analisis Pengaruh Rasio Likuiditas, Leverage, Aktivitas dan Profitabilitas terhadap Return Saham (Studi pada Perusahaan Makanan dan Minuman dengan Kategori Industri Barang Konsumsi di BEJ)". Jurnal Ilmiah Akuntansi dan Bisnis:Vol. 2, No. 1

www.idx.co.id

$\underline{\text { www.yahoofinance.com }}$ 